\title{
Modality in Editorials of Pakistani English Newspapers: A Corpus Based Study
}

\author{
Saba Sadia ${ }^{1} \&$ Mamuna Ghani ${ }^{1}$ \\ ${ }^{1}$ The Department of English, The Islamia University of Bahawalpur, Pakistan \\ Correspondence: Saba Sadia, The Department of English, The Islamia University of Bahawalpur, Pakistan. E-mail: \\ saba_makhdum@yahoo.com
}

Received: October 9, 2018

Accepted: November 5, 2018 Online Published: December 29, 2018

doi:10.5539/ijel.v9n1p144

URL: https://doi.org/10.5539/ijel.v9n1p144

\begin{abstract}
Modality is an important grammatical expression which finds its expression in the editorial section of newspapers in Pakistan. Firstly, this paper deals with the analysis of "Modals" in English and highlights their nature and function. Secondly, it reports on which modal verbs are commonly used by the editors. Thirdly, it is focused on how the modal verbs in Pakistani English newspapers are used to manipulate readers' opinion towards specific issues. For this purpose, a corpus of two Pakistani English newspapers: The Dawn and The News, equally divided by editors, was analyzed wielding concordance tool. The comparative analysis of these newspapers revealed that both the editors chose mainly predictive auxiliary modals such as will and would to the other types of modal. The predictive modal for The News suggested that prediction about the future "what will/would happen" was the major apprehension of the editorial writers. On the other hand, comparing the modals of obligation in the two newspapers, The Daily Dawn was more focused on solution — what should be done.
\end{abstract}

Keywords: modal verbs, corpus, editorials, Pakistani English newspapers

\section{Introduction}

Newspaper editorials have significant importance in newspaper genre. A newspaper presumes that there is always only one reasonable point of view on any matter presented to the public. Fowler (1991) points out that newspaper editorial not only offering values and beliefs but also employ textual strategies i.e., modality is the main concern of this study.

\subsection{Modality: Basic Concept}

The term modality has been observed as a way to express attitudes of the speaker or writer towards the world. Speakers and writers have choice to express certainty, probability, obligation, ability, and obligation in their discourse. According to Simpson (1993), modality is the writer's point of view, "angle of vision", "angel of telling", perspective or authorial interest that determines the essence of story's style that provide the story it's particular "feel" and "color". Kiefer (1994) looked at the modality on the "relativisation of the authenticity of statement meanings to a set of possible words" or the mirror through which public can see the world to be diverse. In other words, modality permits to the language users to express what is, what would be, what may be, and what should be. Modality works like mirror through which people can perceive the world to be different". Modality can give liberty to language speakers to state what is, what would be, what may be, and what should be. By using the syntactical modal patterns, language speakers employ modality not only to make assessment about prospects but also to accomplish the requirement of cross-linguistic description (Palmer, 2007).

Modality deals in presentation of writer and the speaker's world view and ideologies. Fowler (1997) allows interlocutor to speak something without transmitting an outlook to that very thing. It is nearly impossible to find out any written or spoken piece of discourse which is solely objective, impartial, unbiased, or value-free. It is actually about: (i) point of view the writer; (ii) one of the ways of telling something; (iii) angle of vision; (iv) and authorial interest that ascertain the style of the story with its particular feel and color (Simpson, 1993).

Modality is a comprehensive term to describe propositions of the speaker's attitude towards a situation. Modality is considered as an important linguistic device to express social roles and relationship between speaker/writer and hearer/reader. Huddleston (2002) explained the term "modality" using the following examples: 
He wrote it himself.

He must have written it himself.
(1)

(2)

The sentence (1) is considered as unmodalised due to its customary use in which the communicator is committed, without qualification or special stress, to the reality of the proposition uttered. However, the sentence (2) is absolutely modalised. Huddleston and Pullum, (2002) strongly argued that reality of the proposition is not shown as something that is directly known but as something that is inferred.

Modal verbs are the major and best-known among the ways and means for stating modality (Depraetere \& Reed, 2006; de Haan, 2006). Subsequently, modality is a syntactical category typically useed by writers to express their "judgment that a proposition is possibly or necessarily true or that the actualization of a situation is necessary or possible" (Depraetere \& Reed, 2006).

\subsection{Types of Linguistic Modality}

According to Palmer (2007), modality not only holding views about prospective possibilities but it also fulfills the requirements of cross-linguistic description. Linguistic modalities have two types i.e., epistemic and deontic.

\subsubsection{Epistemic Modality}

Epistemic modality deals with evaluation and judgments of the speaker and confidence level which provides bases for proposition. Epistemic procedure, on the other hand, deontic depicts the techniques by which speaker/writer express decision on genuineness of the proposals they speak/write. Palmer (2003) reports that at the end of the day, language users practice epistemic methodology to make conclusions about the possibilities or need of a whole suggestion (p. 7)

\subsubsection{Deontic Modality}

Deontic modality shows how the world can be reflected according to some norms, expectations and desire of speaker. Palmer (2007) viewed deontic modality as generally dependent on some kind of authority given by the speaker. It is related to the methodology by means of which the users of language make judgment in which forthcoming happenings are obligatory, promising and required. Deontic modality, according to Palmer (2003), can be interpreted as the "manifestation of the conclusion of likelihood plus acceptability or need including compulsion of an action, event or state by a speaker" in which regulator of the action, event or state is outsider to the subject of the clause. Overall, it is "dependent on speaker's authority" (Palmer, 2007); to the contrary, the aptitude of a happening derives from the consent given by the speaker or by any other authority contrasting to that subject (Palmer, 2003).

\subsection{Functions of Modality}

There are different degrees of function of possibility, certainty and obligation that are actually called values, which are classified into high, median and low values as are given in the table below:

Table 1. Three values of modality: Haliday (1994, p. 362)

\begin{tabular}{ll}
\hline High value & Must, Should, Ought to, Need to, Has to, Is to \\
Median value & Will, Would, Shall \\
Low value & May, Might, Can, Could \\
\hline
\end{tabular}

\subsubsection{Prediction}

Prediction is used as a modal auxiliary and makes estimate about an event, situation, happening, and act. Basically, it is used to make prediction which is not definite. According to Halliday (1994), modal of prediction possessed median value of modality which leads editorial writer to the mid attitude towards an event.

\subsubsection{Obligation}

Should is preterit form of shall that indicates an act that is considered by the speaker to be obligatory as (you should go) in which an agent is obliged to do something. It indicates duty, expediency and expresses condition that makes a statement less direct. It makes formal request or offer.

\subsubsection{Possibility/ Ability}

Leech (1969) claims that possibility and ability meaning is very common than the permission. Modal "can" mostly shows strong possibility. Modal auxiliary could deal with meaning of possibility, it also gives evidence about an ability that someone has in past and it expresses the degree of possibility in which something is performed. On ther 
other hand, modal auxiliary "may" is mostly used for possibility in present and future time, and a situation in which something is possible that makes possibility of action, situation or any condition in which something is done. "Might" expresses agent doubt about truth of proposition and also talks about possibility that indicates possibility or probability in the past. Might is the past form of "may" and refers to those events that have already happened in past.

The most important point here is that the difference in value leads to a different kind of attitudinal stance on the part of the speaker. Boulomoic modality is a subcategory of Deontic modality which describes the desire of the speaker as "I wish" "I hope" etc. Perception modality explains commitment to the validity of a preposition that is based on some reference to human perception (Perkins \& Simpson, 1983-1993). This theoretical modal is basically a tool for analyzing text from media discourse which includes newspaper text.

Table 2. The relationship between the modal system and non-linguistic concepts.

\begin{tabular}{ll}
\cline { 2 - 2 } Modal system & Non -linguistic concepts represented \\
\hline Deontic & Obligation, duty, and commitment \\
Boulomaic & Desire \\
Epistemic & Knowledge, belief, and cognition \\
Perception & Perception \\
\hline
\end{tabular}

Simpson (1993, p. 51).

\section{Literature Review}

Keeping in view the significance of modality, several research studies have been conducted striving to shed light on its utility and occurrence in written discourse. Flower (1986) carried out a research study claiming mood and modality as the grammar of explicit comment. It is the way through which people express their degree of commitment to the truth of the propositions they make. In this context, modality seems something which presents ideological point of view of a writer. Hence, modality provides ample space to the editorial writers to present their principles and approaches towards the text.

While expressing the patterns of modality in media discourse, Iwamato (1998) stressed on newspaper articles and the outcome of his study revealed that articles in newspapers employed frequent high-value deontic modality e.g., must, should, ought to, need to, deprived of nearly any emotive types of modality e.g., I wish, I hope, I regret. Moreover, in order to transmit an inferior level of conviction and guarantee on the part of the writer with reference to propositional material, the writers used lesser value epistemic modality like may, might, can, and could.

Gotti (2003) emphasizing on the Helsinki Corpus of English Texts, discovered that shall was "commonly used in speech-based prose" in comparison to a "very low normalized figures for SHALL-forms in scientific texts". Smith (2003) concentrated on the diachronic change of have to and figured out that the use of have to was "most focused in the literature and mass media, with evolution being most substantial in the mass media reportage unit". Such research studies have figured out that modality might echo common characteristics of a specific genre.

F. R. Palmer (2007) expressed mood and modality in a typological way. He carried out basic task in the research study of mood and modality in a typological way (Palmer, 2007). He focused on the lexical arrangements of modality and a variety of modal manifestations across languages. He figured out that modality can be categorized into two sets, namely propositional modality and event modality. In addition, he combined the classic dichotomy of epistemic and deontic modalities arguing that propositional modality comprises on epistemic modality and evidential modality though, event modality covers deontic modality and dynamic modality.

According to Palmer (2007), epistemic modality symbolizes the speaker's "conclusions about the genuine position of the proposition", while evidential modality mirrors "the evidence" the presenter has for its "factual status". When we talk about likelihood or inevitability of a problem, we seem keen to employ epistemic modality, which is also known as "inference" in a cognitive sense. Deontic modality, on the other hand, relates to "obligation or permission", power from the external world, whereas dynamic modality delivers the "ability or readiness, one of the inner feelings".

Qun (2010), using corpus analysis methods, carried out an exploration to disclose the features of modality in educational papers and newspaper editorials. The results of this research exposed that scientific research papers avoid epistemic modals like I think, and surely, because of the stress on offering an objective interpretation of the news events. Despite being objective, scientific papers also vindicated their assessments in an emphatic, reliable 
and rational way; thus the frequency of often was greater than the presence of usually and sometimes.

With reference to the printed editorials, conclusions of Qun's research study also pointed out that should and could were the noticeable features in editorials. A probable rational for such priority was that a large majority of editorials tried to express their opinion on happenings which had already taken place, therefore the past participle was given the priority. On the contrary, however editorial writers have ever strived to present their standpoint in an explicit manner to prevent their readers get offended. Therefore, they opted to use justifying modal verbs like could and might.

Moreover, editorial writings had frequent occurrences of perhaps whereas scientific research papers preferred to employ may more regularly. In fact, the editorial journalists were trying to avoid expected criticism by giving an uncertain point of view in their writings by using such words like perhaps. On the other hand, if scientific editorial writers had employed this word extra regularly, the objectivity and genuineness of their scientific findings would appear suspicious.

In view of the significance of modality in operating communal reality, the present study, then, endeavors to present the lingual expression of the notion in the particular editorials of daily English Newspapers i.e., Dawn and The News International

Taking in account the significance of modality in manipulating reader's opinion, the current study is focused on linguistic expression of the concept in the selected Pakistani English newspapers' editorials i.e., The Dawn and The News.

\section{Methodology}

In the current quantitative study, a corpus of thirty copies of Pakistani English newspapers-Dawn and The News International was analyzed to investigate the modal verb type the editors of "The News International" and "Dawn" make maximum use of in their respective editorial sections.

\subsection{The Corpus}

The corpus comprised on a selection of editorials from leading newspapers i.e., The News International and Dawn. One of the reasons behind choosing these editorials was that the renowned authors write these editorials and they are highly credible. A total number of 30 editorials were selected from both newspapers for the month of January, 2015. Of the thirty, 15 entitled "The News International" and the rest were those of "Dawn". The word range of editorials was 10,000 words per newspaper. The corpus was retrieved from the official websites of both groups of newspapers.

\subsection{Data Manipulation}

Once the corpus was compiled and converted into plain text file, a software "AntConc" 3.4.4w version (concordance tool) was run to isolate modal verbs from the editorials of the newspapers included in the corpus. AntConc provides multiple options to analyze linguistic features of text. By the use of these tools researchers can analyze different features of text. Key word list shows total number of words in a corpus and Concordance tools explains frequency of explored piece with reference to their context. There are multitude options in Antconc software as: concordance tool, file view, clusters, collocates, and N- grams that researcher can use according to their research purpose.

In present study, "concordance" was most useful tools, because frequency of total modal verbs in all newspapers' editorials is known by this tool. Secondly, concordance plot shows use of every modal verb in their appropriate context. So in this way, it is very easy to know how many times a modal verb performs various functions in all these newspapers as possibility, obligation, prediction, and ability. The responses of the software were further analyzed via descriptive statistics. The analysis focused on the percentage of the number of modal verbs employed in each of the two groups of newspapers to get at: (i) the type of modals the editors use to the maximum; (ii) the newspaper which exploits more modal of same type than the other; (iii) and the modals the editors exploit keeping in view their peculiar function in order to steer the readers' ideology to their favorite directions.

\section{Results and Discussion}

Modality in the editorial section of Dawn and The News was expressed via different textual strategies such as modal auxiliaries and modal adverbs. However, the distribution of modality through modal auxiliary is vital in this study. The results from the concordance tool were categorized according to the functions the modal verbs perform. 
Table 1. Average function-wise ratings of modal verbs

\begin{tabular}{|c|c|c|c|c|c|}
\hline $\begin{array}{l}\text { Function of Modal } \\
\text { Verbs }\end{array}$ & $\begin{array}{l}\text { Modal } \\
\text { Verbs }\end{array}$ & $\begin{array}{l}\text { No. of Occurrence in } \\
\text { Dawn }\end{array}$ & $\begin{array}{l}\text { Cumulative \%age of } \\
\text { Occurrence }\end{array}$ & $\begin{array}{l}\text { No. of Occurrence in } \\
\text { The News }\end{array}$ & $\begin{array}{l}\text { Cumulative \%age of } \\
\text { Occurrence }\end{array}$ \\
\hline \multirow[t]{2}{*}{ Prediction } & Will & 37 & $45 \%$ & 49 & $76 \%$ \\
\hline & Would & 16 & & 46 & \\
\hline \multirow[t]{3}{*}{ Obligation } & Must & 12 & $22 \%$ & 02 & $11.2 \%$ \\
\hline & Should & 14 & & 12 & \\
\hline & Can & 24 & & 05 & \\
\hline \multirow[t]{3}{*}{ Possibility/ Ability } & Could & 07 & $33 \%$ & 09 & $12.8 \%$ \\
\hline & May & 06 & & 0 & \\
\hline & Might & 02 & & 02 & \\
\hline Total & & 118 & $100 \%$ & 125 & $100 \%$ \\
\hline
\end{tabular}

It follows from data that the editors used two modal verbs will and would to the maximum in the editorial sections of their respective newspapers and that The News International outstripped Dawn in its choice of these two modal auxiliaries. It means that the editors of The News international construe the capacities in the use of will and would and they make the fullest use of the actual function of ibid modals than the editors of Dawn to construct their readers' comprehensibility of any event propounded in the editorial section. In doing so, they tend to build the mind set of their readers towards guessing and/or forecasting of the events which leads the point of view of the reader towards (un)certainty.

While comparing the twofold function of modal verbs, which is obligation (must and should) and possibility/ability (can, could, my, and might), the editors of Dawn put more emphasis on "what should be done" and "what could be done". The reason behind focusing on the said functions is that these modal verbs lead the reader towards the certain situations which help them to make their point of view clearer. On the other hand, editors of The News International have shown least interest in using ibid. modal verbs. Hence, it can be said that Dawn newspaper is playing its positive role in disseminating information among its readers.

\subsection{Model Verbs and their Two Fold Function}

\subsubsection{Examples for Prediction}

i. If the right to appeal is maintained, the government will be hoping that the superior courts will decide appeals based on the lower threshold of evidence, and fewer due-process and fair-trial protections, that military trial courts require, and not the higher threshold that the regular court system allows.

(Dawn: 5/1/2015)

ii. It would suggest that the political class is at least aware of the disastrous consequences of allowing the military to completely usurp the judicial process.

(Dawn: 5/1/2015)

iii. If we could not do it, there will be no justification for us to continue to hold our positions, he remarked.

(The News: 7/1/2015)

iv. He did not say when that $\underline{\text { could }}$ happen.

(The News: 8/1/2015)

In the above extracts, the writers of these editorials not only provided the information but also showed their own outlook towards the events by using certain modal auxiliaries. In example (i), the editor of The Dawn showed strong possibility that the courts should make decision while considereing the lower thresholds. On the other hand, in example (iii), editor of The News showed mild possibility when using "will" in the context of holdiing position.

Whereas, in example (ii), the editors suggested that political people should have knowledge to understand the consequences of military decision, which could be have a bad impact on the civil society. However, in example (iv), the editors argued that judicial process for decision could happen any moment without considering the civil aspirations.

\subsubsection{Examples for Obligation}

i. There can be no argument that Pakistan circumstances have for years made it a dangerous country in which journalists $\underline{\text { must }}$ discharge their professional obligations. 
ii. The Election Commission of Pakistan should tell us what the point is of asking politicians to declare their assets when no action is taken on the basis of the information collected.

(Dawn: $1 / 1 / 2015$ )

iii. Military courts need not record evidence which is already recorded; govt.'s permission $\underline{\text { must }}$ for terrorists' trial.

(The News: 4/1/2015)

iv. The JUI-F chief said he should have the right to submit a petition in the Supreme Court against the establishment of special courts.

(The News: 7/1/2015)

In examples from "Dawn", (v), must worked as high level modality rather than example (vii) which is from The News. Both examples showed obligation to agent to deal with the issues according to the situation. Whereas, example (vi) showed string obligation on the decision of Election Commission of Pakistan on declaring the assets of politicians. However, in example (viii), should promulgated mild obligation of JUI-F chief remarks.

\subsubsection{Examples for Possibility/ Ability}

v. Still, the ground between not wanting a fight and learning to avoid one can be wide

(Dawn: 2/1/2015)

vi. Voices that regularly claimed that the war on terror was not our war or that the mass murder of civilians $\underline{\text { could }}$ be attributed to America drone attacks have been silenced in the wake of the massacre of schoolchildren in Peshawar.

(Dawn: 7/1/2015)

vii. This $\underline{\boldsymbol{m a y}}$ be a more time-consuming exercise but is perhaps the most effective and safest.

(Dawn: 2/1/2015)

viii. The three Al Jazeera correspondents $\underline{\boldsymbol{m i g h t}}$ have talked to opposition leaders, including Brotherhood sympathizers, and reported for their channel. But that doesn't constitute a crime.

(Dawn: 3/1/2015)

ix. English authors $\underline{\boldsymbol{c a n}}$ muster a sale of between 3,000 and 5,000, but that includes primarily pirated copies.

(The News: 7/1/2015)

x. Bangladesh will consider making changes to a proposed law that journalists and countries such as the United States say could suppress free speech, a government minister said on Sunday after a meeting with a group of editors.

(The News: 8/1/2015)

xi. "We assured them that if the cabinet agrees, then we may make some amendments.

(The News: 17/1/2015)

xii. Fazl-ur-Rehman said such bills $\underline{\text { might }}$ cause a divide among the people, alleging that various groups were being treated discriminately under the 21st Constitutional Amendment Bill and The Army Act Amendment.

(The News: $17 / 1 / 2015$ )

In example (ix) can is performing the function of ability in comparison with the example (xiii) which carries the meaning of possibility of increasing the sale of books from 3,000 to 5,000. While comparing example (x) and (xiv), modal verb could in (x) is expressing chance of America's involvement in drone attack. On the other hand, in (xiv) could is attributing with function of ability that Bangladesh could be able to say suppress-free speech. Whereas, comparing example (xi) and (xv), may is performing a different function. In (xi), may is featuring as possibility about the exercise which could be more time-consuming, though in (xv), it is again weighing the meaning of ability to make amendments in cabinet. In the last, example (xii) and (xvi), both expressing might has strong possibility.

In present study, the use of modal auxiliaries was analyzed in two leading Pakistani English newspapers. Both newspapers are published on daily basis in Pakistan and different countries of the world. Dawn is the oldest among all while The News International is among the modern newspapers. The analysis of selected editorials in both Dawn and The News International not only presents the editors' point of view, they also invite readers' opinions and observations through the use of modality. Modal verbs are interesting because of their semantic bond with the events and information presented in editorials.

An evaluation of the two types of newspapers in terms of use of auxiliary modal verbs recommended that both of the newspapers favored mainly predictive auxiliary modals such as will or would to the other kinds of modals. But the higher number of the predictive modals in The News International $(\mathrm{N}=95)$ suggested the idea that identifying 
"what would happen in the future" was the main concern of the editorial writers in The News International. On the other hand, comparing the modals of obligation in two of the papers (Dawn 22\%, The News International 11.2\%) suggested that editorial writers in Dawn were occupied with "what should be done". Moreover, the editors of Dawn give emphasis more on possibilities/abilities and put forward the idea to its readers about the prospective decision or results. Henceforth, expressing modality mainly through modal auxiliary verbs confirmed the results of the study carried out by Morley (2004) who accepted the greater significance of modals in editorials compared with news reports. Alireza Bonyadi (2011) conducted a similar study on native and non-native newspapers editorials i.e., New York Times from America and Tehran Times from Iran, respectively. The study included 40 editorials, having 20 from each newspaper. Results revealed that both the newspapers favored predictive auxiliaries, such as will and would. Frequent use of modal verbs in the newspapers provided convenient contextual view to its readers. The results of the current study are somewhat contrary to it. The use of modal auxiliaries varies within the same context which means the purpose behind dissemination of information varies from newspaper to newspaper.

The results of the study conducted by Iwamato (1998) are dissimilar to present study. He analyzed patterns of modality in newspaper articles. Finding explored that articles writers used frequent high-value deontic modality i.e., must, should, ought to, need to devoid of nearly any emotive types of modality such as I wish, I hope, I regret. Furthermore, in order to convey some low-grade level of opinion and guarantee on the part of the writer with reference to propositional material, the writers used lesser-value epistemic modality like may, might, can, and could.

\subsection{Academic Implications}

From academic point of view, the interface among the linguistic analysis of newspaper editorials and the teaching of English in EFL and ESL settings, it would be a pertinent issue if one considers the increasing number of students particularly in English language studies in Pakistani universities. The students of English language subject can take not only benefit from such a comparative study and analysis of linguistic items but also it may boost their linguistic awareness in the newspaper genre. Newspapers provide a wide-ranging diversity of its sub-genres i.e., the use of standardized language and up-to-date content which have transformed the application of newspaper as language teaching materials.

Specially, the newspaper editorials can also be used in teaching academic reading and writing and especially in the subject of journalism. The effective use of newspaper in teaching can facilitate beyond the limits of curriculum. Newspapers are not only easily available but also they contain a diverse variety of genres and sub-genres which can be helpful in enriching linguistics range for a language learner.

\section{Conclusion}

It may be said, in view of the data, that newspapers are not only aimed at reporting and presenting information on news events but also steering the readers towards a particular bent of mind and that is done via modality on the part of the editors of the newspapers. While commenting on same issue in their editorials, different editors make vulpine use of sundry modal verbs to promulgate one idea or other of their own choice. Modality is realized in said newspapers through modal auxiliary verbs. The analysis of the selected editorials indicated that editorial writers of Dawn are more likely to spread authentic information among readers than the editorial writers of The News International.

\section{References}

Bonyadi, A. (2011). Linguistic Manifestation of Modality in Newspaper Editorials. International Journal of Linguistics, 3. https://doi.org/10.5296/ijl.v3i1.799

Depraetere, I., \& Reed, S. (2006). Mood and modality in English. In B. Aarts \& A. McMahon (Eds.), The handbook of English linguistics (pp. 269-290). Malden / Oxford / Carlton: Blackwell. https://doi.org/10.1002/9780470753002.ch12

Fasold, W. R., \& J. Connor-Linton (2006). An introduction to language and linguistics. Cambridge: Cambridge University Press.

Fowler, R. (1997). Linguistics and Novel. London: Methuen.

Gotti, M. (2003). Shall \& Will in Contemporary English: A Comparison with Past Uses. In R. Facchiretti, M. Krug \& F. Palmer (Eds.), Modality in Contemporary English. Berlin and New York: Mouton de Gruyter. https://doi.org/10.1515/9783110895339.267

Halliday, M.A.K. (1994). An introduction to functional grammar (2nd ed.). London: Edward Arnold. 
Huddleston, R. D., \& Pullum, G. K. (2002). The Cambridge Grammar of the English Language. Cambridge: Cambridge University Press. https://doi.org/10.1017/9781316423530

Iwamoto, N. (1998). Modality and point of view: A contrastive analysis of Japanese wartime and peace time newspaper discourse. In B. Parkinson (Ed.), Edinbugh working papers inapplied linguistics (pp. 17-41). University of Edinburgh.

Kiefer, F. (1994). Modality. In R. E. Asher (Ed.), The Encyclopedia of Language and Linguistics (pp. 2515-2520). Oxford: Pergamon Press.

Leech, G.N. (1969). A linguistic guide to English poetry. London: Longman

Palmer, F. R. (1990). Modality and the English modals (2nd ed.). London: Longman.

Palmer, F. R. (2003). Modality in English: Theoretical, Descriptive, and Typological Issues. In R. Facchinetti, M. Krug \& F. R. Palmer (Eds.), Modality in Contemporary English (pp. 1-17). Berlin: Mouton de Gruyter. https://doi.org/10.1515/9783110895339.1

Palmer, F. R. (2007). Mood and Modality. Beijing: World Book Publishing Company.

Perkins, M. (1983). Modal expressions in English. London: Frances Pinter.

Qun, Z. (2010). Modality and generic features in Chinese EFL writing. Chinese Journal of Applied Linguistics, 5(33), 40-51.

Simpson, P. (1993). Language, Ideology and Pont of view. London: Routledge. https://doi.org/10.4324/9780203312612

Smith, N. (2003). Changes in the Modals and Semi-modals of Strong Obligation and Epistemic Necessity in Recent British English. In R. Facchiretti, M. Krug, \& F. Palmer (Eds.), Modality in Contemporary English (pp. 241-266). Berlin and New York: Mouton de Gruyter. https://doi.org/10.1515/9783110895339.241

Sulkunen, P., \& Törrönen, J. (1997). The production of values: The concept of modality in textual discourse analysis. Semiotica, 113(1/2), 43-69. https://doi.org/10.1515/9783110895339.241

\section{Copyrights}

Copyright for this article is retained by the author, with first publication rights granted to the journal.

This is an open-access article distributed under the terms and conditions of the Creative Commons Attribution license (http://creativecommons.org/licenses/by/4.0/). 